\title{
High Pressure and High Temperature Wells Cementation using Calcium Oxide Additives: Review
}

\author{
Amosu C.O.
}

\begin{abstract}
The challenges created by HPHT conditions make drilling and cementing difficult. The overwhelming challenge stands for materials used for wells operated at higher temperature and pressures in the face of producing downhole. There is need for better choice of cement for cementing operations during development and production of wells. The review method is adopted in this article considering Calcium Oxide which poses as good cement expander. In this paper, a broad overview of the fundamental understanding and use of calcium oxide as additive is considered for cementation of HPHT production wells will be discussed.
\end{abstract}

Keywords: High, Pressure, Temperature, Cement, Calcium, Oxide, Production.

\section{INTRODUCTION}

A. High Pressure High Temperature Wells

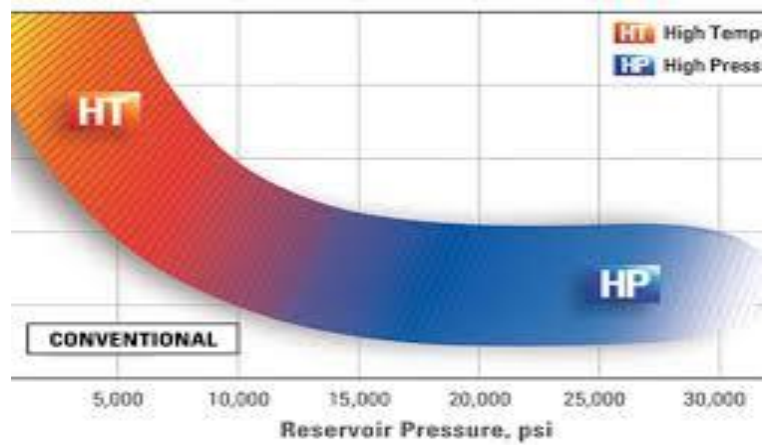

High pressure/high temperature (HP/HT) wells are those that are at greater temperature or pressure than most other oil wells having downhole (Shado and Ogbonna, 2011) temperature and pressure that ranges between $150-200^{\circ} \mathrm{C}$ and $70-140 \mathrm{MPa}$, with maximum projected pore pressure of porous formation which exceeds about $0.8 \mathrm{psi} / \mathrm{ft}$ of hydrostatic gradient, or has rated working pressure in excess of about 10000 psi at their farthest depth (Arpit et al., 2019). Wells in this categories and conditions display challenges. HPHT are pushing workable limits for engineers working bottomhole and for manufacturers in fluid control components to ensure products continue to meet these challenges (Woha, Ogbonna and Boniface, 2011).

Manuscript received on 08 May 2021 | Revised Manuscript received on 10 May 2021 | Manuscript Accepted on 15 May 2021 | Manuscript published on 30 May 2021.

* Correspondence Author

Amosu C.O.*, Department of Mineral and Petroleum Engineering, Yaba College of Technology, Yaba. Email: cyril.amosu@yabatech.edu.ng

(c) The Authors. Published by Lattice Science Publication (LSP). This is an open access article under the CC-BY-NC-ND license (http://creativecommons.org/licenses/by-nc-nd/4.0/)

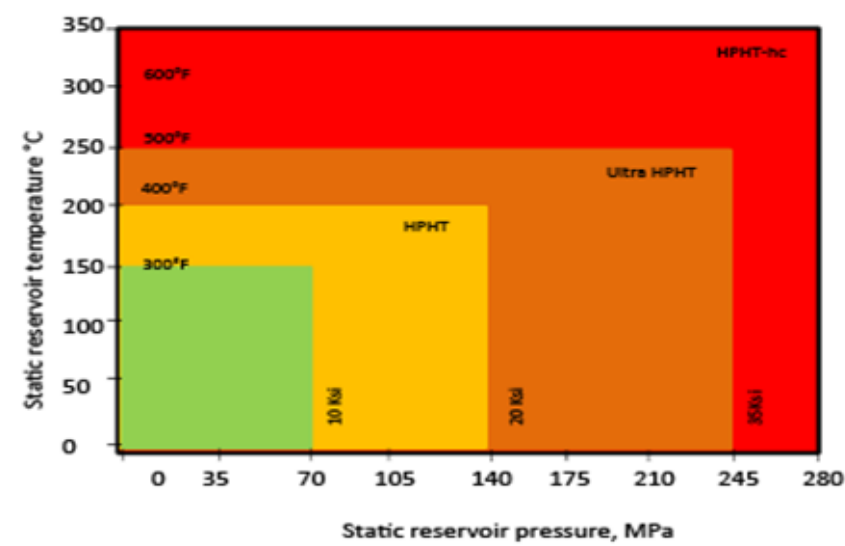

Figure 1: Static Reservoir Temperature against Static Reservoir Pressure (researchgate.net).

Other challenges produced by HPHT situations make drilling/completion and cementing operations difficult which should be addressed for execution of successful job and delivery of perfect job (Zhaoguang, 2012). Temperature speeds up the process of hydration in cement, hence limiting the time it stays alterable slurry in the well. This aim refers to its ability to flow inside a defined operational window. The hydration process can chemically be delayed by the inclusion of retarders. The primary objective of cementing is maximizing cement coverage. The secondary purpose are casing protection, zonal isolation which can achieved in the annular gap if the presence of cement is optimised and maximized (Boma, Babs and Islam, 2016). During cementing, cement coverage is possible only if mud is absolutely displaced from the hole. Furthermore, one of the most challenges in HPHT is the rheology of cement slurry. It is common in HPHT wells to have a narrow margin (Michael et al, 2017) between fracture and pore pressure limiting the allowable displacement rates and ECD, not to surpass the fracture gradient. The exact implications for cement slurry and its placement is the lower pumping rates due to limited Equivalent Circulating Density (ECD) which prevent achieving proper density but having demands on chemicals concentrations, especially retarders, to cause longer thickening times

Features of High-Density Cement Slurry:

1. They are hard to mix at surface because they are dependent strictly on temperature and because of their high solid content which supports settling and/or gelling.

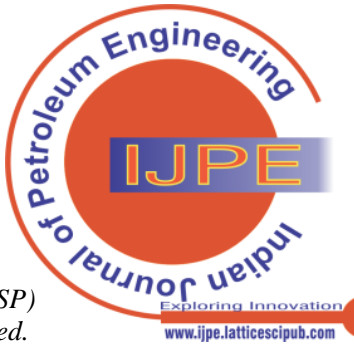


2. It demands a careful and conscious design taking cognisance of variations in temperatures, density and concentration of additives.

3. It must be stable and able to pump at elevated circulating temperature and at surface.

4. It must be retarded more than enough and yet be able to set at lower temperatures at the top of the cement.

\section{Cement Slurry Design Criteria for HPHT}

1. Surface conditions of $300 \mathrm{rpm}$ reading and yield point lower than $35 \mathrm{lbs} / 100 \mathrm{ft}^{2}$;

2. Condition HPHT consistometer at $185{ }^{\circ} \mathrm{F}$ and yield point higher than $10 \mathrm{lbs} / 100 \mathrm{ft}^{2}$.

3. Monitor the temperature stability of the drilling fluid using $\mathrm{HP} / \mathrm{HT}$ rheometer or viscometer to evaluate its rheological properties at up to $260^{\circ} \mathrm{C}$ and $20,000 \mathrm{psi}$

4. Ramp-up and down readings at different speed. Settling tendency and gelling tendencies will be indicated.

5. Condition HPHT consistometer to less than $30 \mathrm{Bc}$

6. Shut-off motor and check for a consistency spike in the HPHT consistometer. Static gel strength development is indicated.

7. Free fluid to zero with a test if well is deviated

8. Static Sedimentation test, less than $5 \%$ deviation from theoretical density;

9. Use stirred fluid loss cell and API fluid Loss that is less than $50 \mathrm{ml}$ per every 30 minutes.

10. Run rheology and thickening time using mud/spacer/cement compatibility test.

11. Run sensitivity tests using retarder concentration of about 0.02 gallon per second and density of about 0.3 part per gallon.

*Avoid excessive time from reaching 50 psi compressive strength to reduce a longer wait-on-cement.
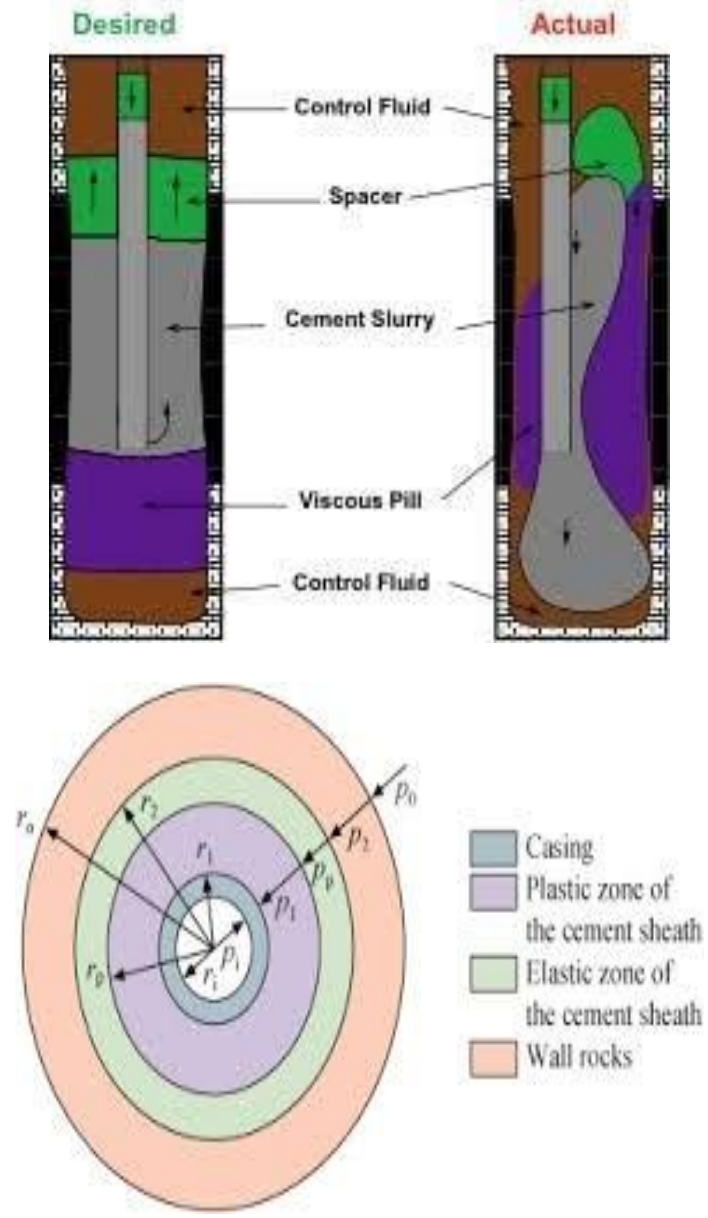

Retrieval Number:100.1/ijpe.A1901051121

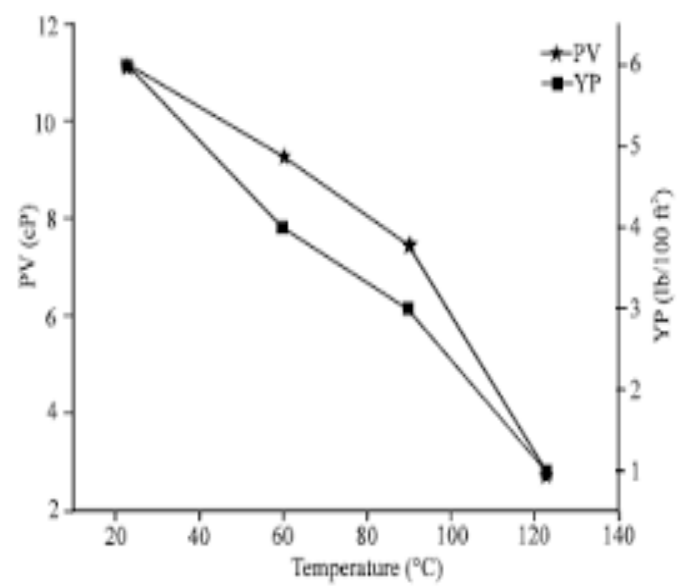

Figure 2: Guideline for Cementing (better-cementingfor-all.org, sciencedirect.com and scialert.net)

\section{Well Construction in HPHT}

The HPHT condition implicates several challenges, with wells often deep and having narrow pressure operational window, undesirable long non-productive times and higherthan-planned costs. Proper cementing can provide tremendous benefits to keep positive well economics.
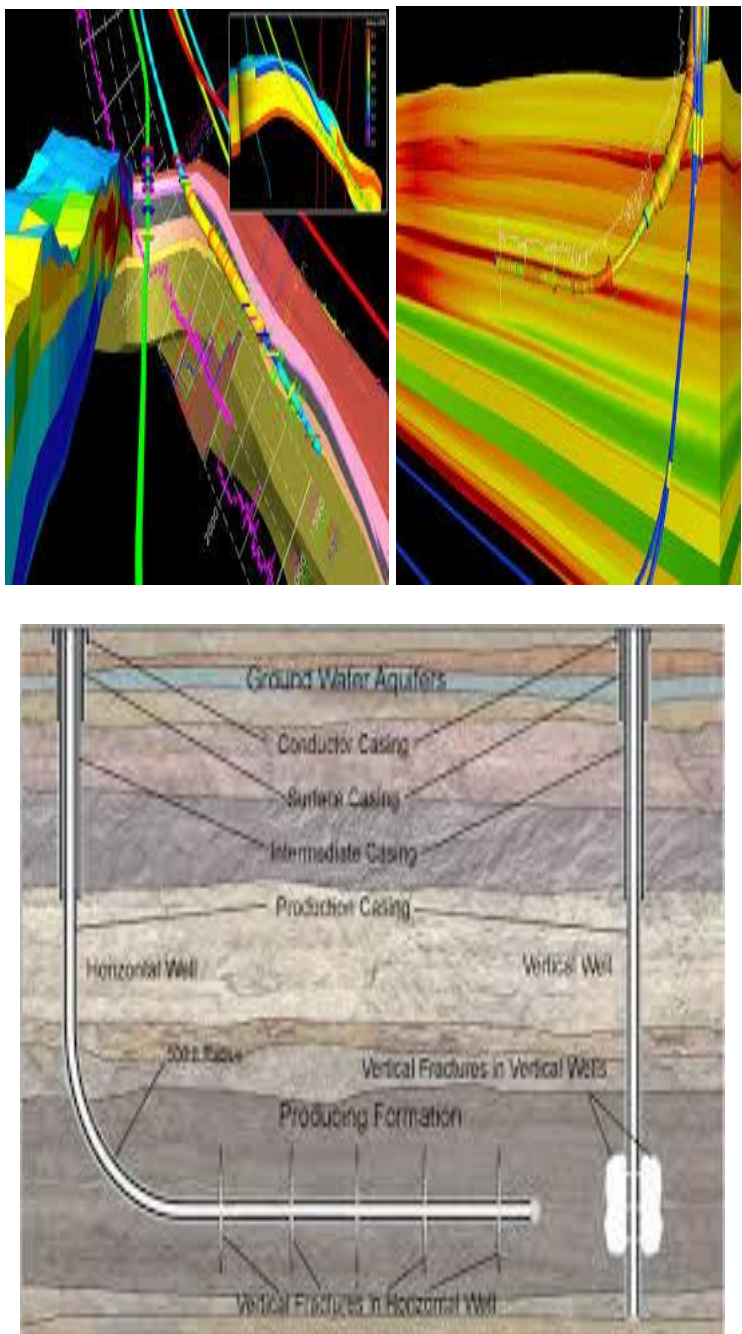

Figure 3: Planning HPHT Completion Challenges

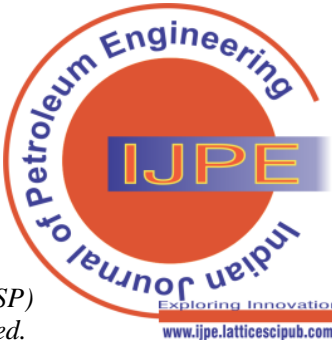



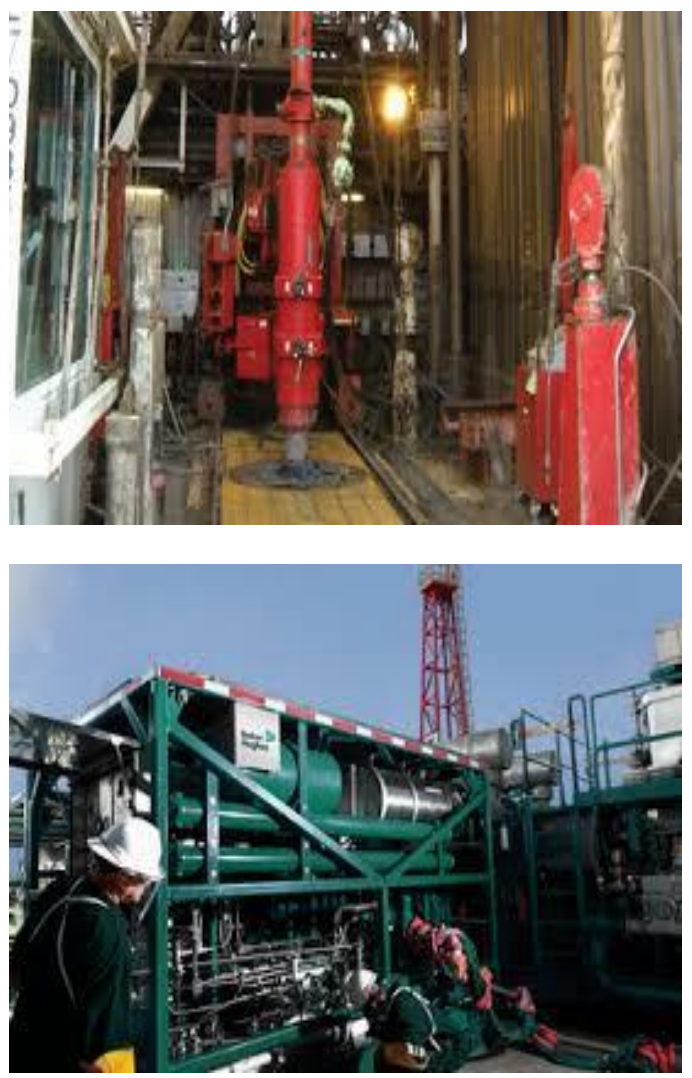

Figure 4: Wellbore cementing

One side deforms shaply while another slightly

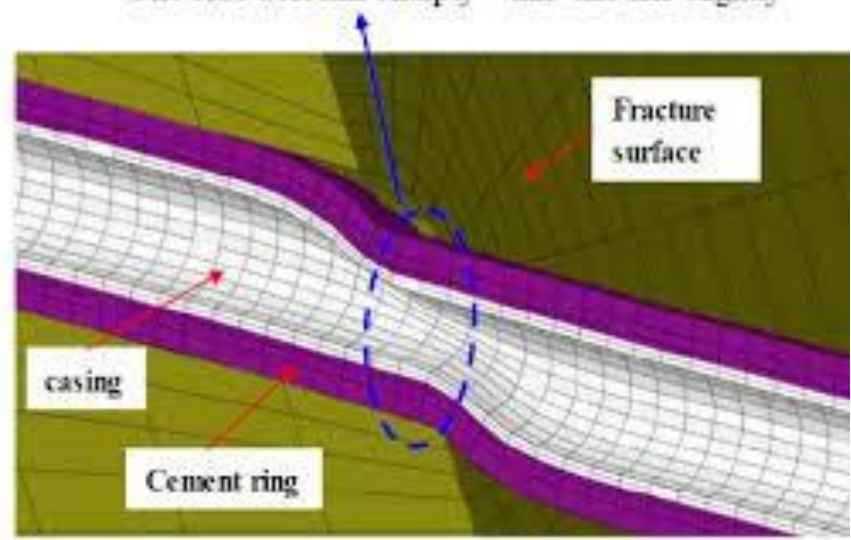

Figure 5: Casing Structural Integrity (rgurepository.worktribe.com)

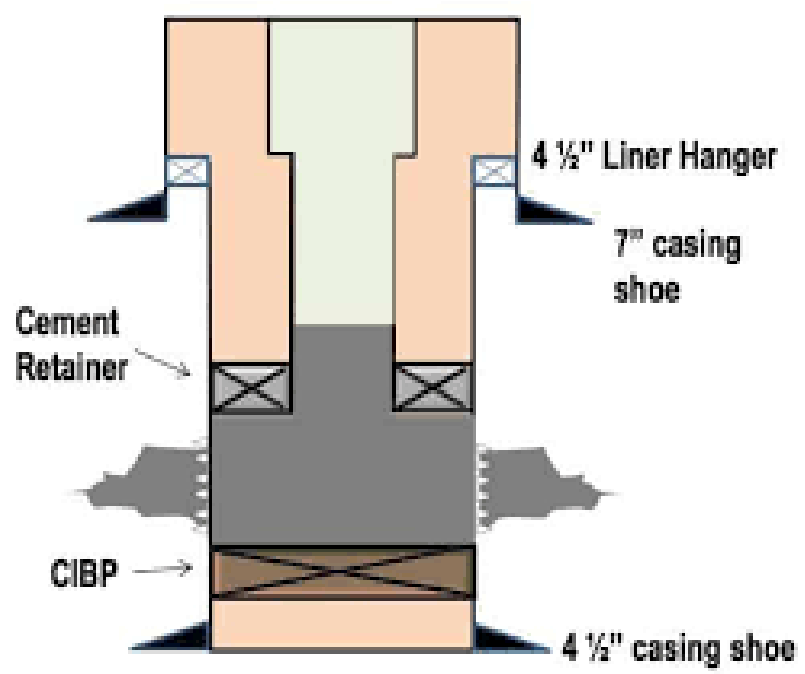

ISSN: 2582-9297 (Online), Volume-1 Issue-1, May 2021

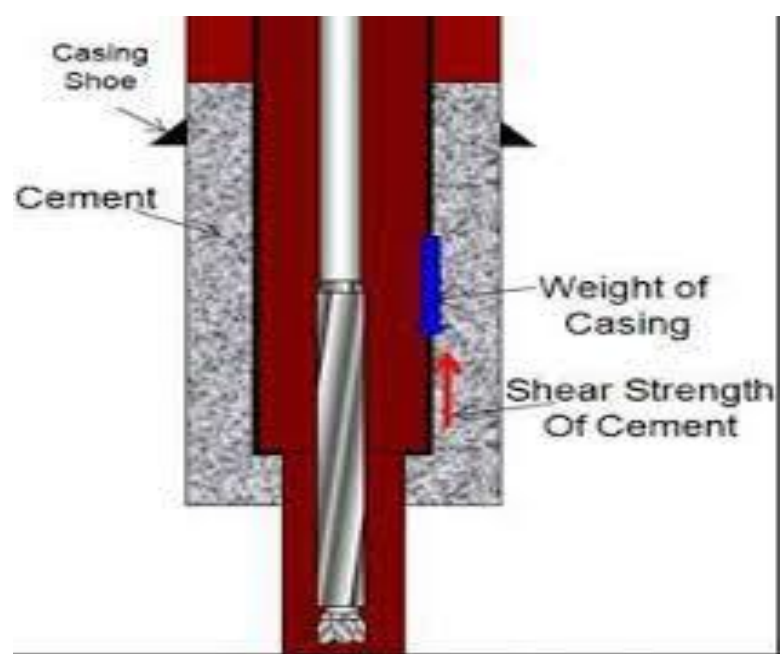

Figure 6: Squeezed Cementing (wellideas.com)

B.

$$
\text { Calcium Oxide }
$$
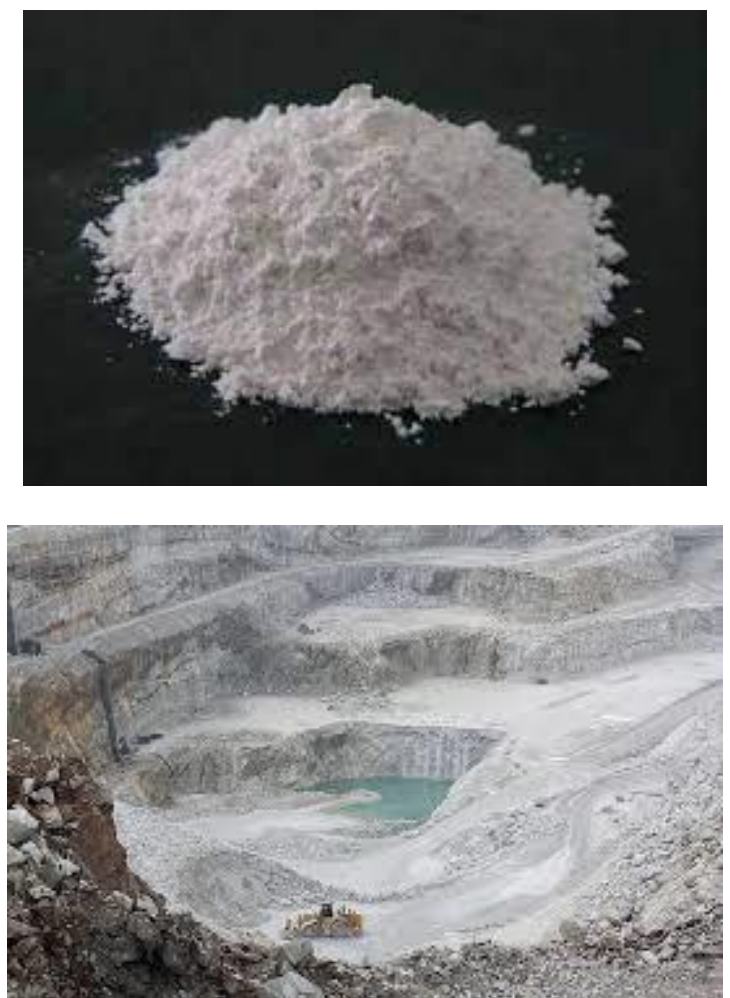

Figure 7: Sample and Outcrop of Calcium Oxide Mining Site (brenntag.com and civiljungle.com)

Calcium oxide, also known as quicklime, is a chemical compound and alkaline substance with the formula $\mathrm{CaO}$. Calcium oxide molecules contain one calcium cation (which holds a charge of +2 ) and one oxygen anion (which holds a charge of -2), i.e. $\mathrm{Ca}^{2+} \mathrm{O}^{2-}$. It is the key ingredient for the process of making cement. The tests on CaO-type expansive cements to isolate gas entry, for some years, has produced great interest in oil well cementing.

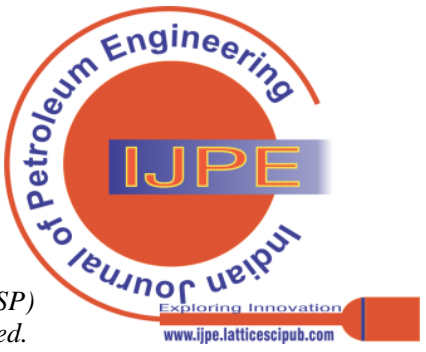




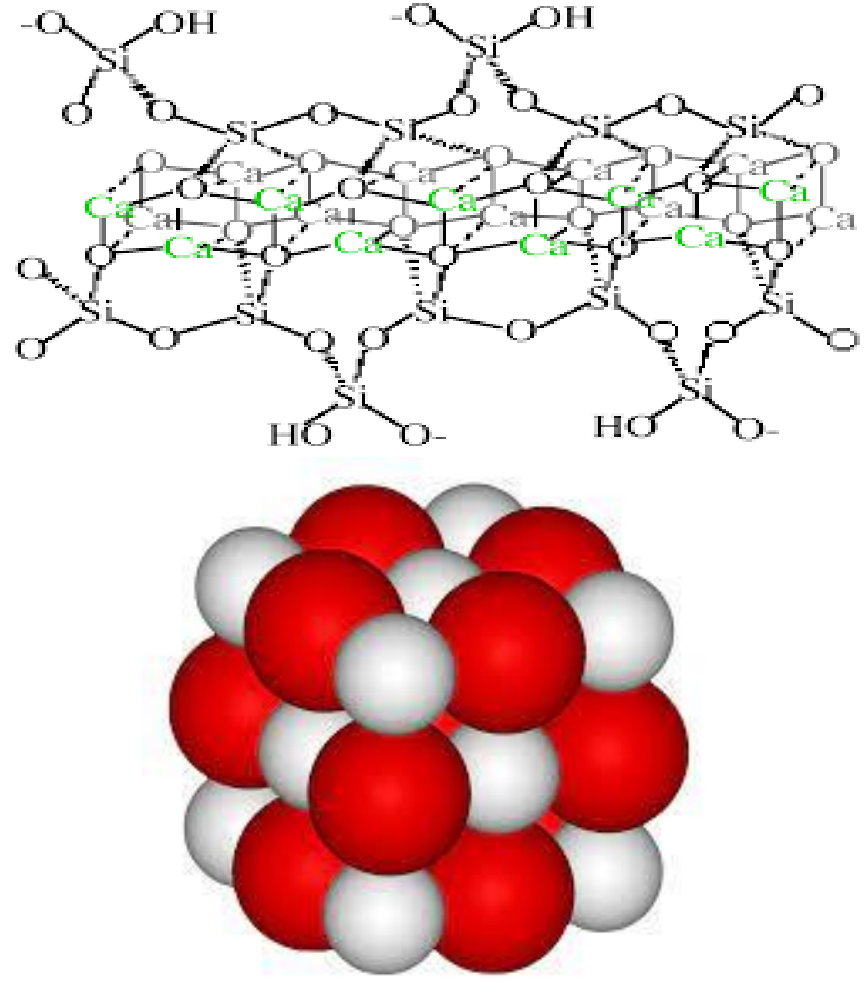

Figure 8: Chemical structure of Calcium Oxide (cnx.org)

Calcium Oxide has the following properties:

(a) It is an amorphous white solid.

(b) It is an ionic compound featuring an ionic bond between calcium and oxygen.

(c) It is soluble in water and glycerol.

(d) Its molar mass is $56.0774 \mathrm{~g} / \mathrm{mol}$.

(e) Its density is $3.34 \mathrm{~g} / \mathrm{cm}^{3}$.

(f) It is basic in nature and forms salts when it comes in contact with an acid.

(g) It forms slaked lime in the presence of water, i.e. $\mathrm{CaO}(\mathrm{s})+\mathrm{H}_{2} \mathrm{O}(\mathrm{l}) \rightarrow \mathrm{Ca}(\mathrm{OH})_{2}(\mathrm{aq})$

(h) Its melting point is $2572^{\circ} \mathrm{C}$.

(i) Its boiling point is $2850{ }^{\circ} \mathrm{C}$.

(j) It is a very stable compound and withstands high temperatures.

(k) Its standard molar entropy corresponds to 40 joules/mole kelvin.

(l) It crystallizes in a cubic crystal

(m) It emits an intense glow when heated to temperatures above $2400^{\circ} \mathrm{C}$

(n) It reacts with water to release enough heat which can ignite combustible materials.

(o) It is favourable heterogeneous base catalysts

(p) It is nontoxic

(q) It has low solubility in methanol

(r) It has a medium viscosity

(s) It has a high surface tension

(t) It has a high to intermediate expansion and contraction rate

(u) It is not volatile at ceramic temperatures.

(v) It has a moderate effect on colour,

(w) It has a bleaching effect on iron oxide.

(x) It exists in the colour of kaki/tomato reds.

(y) It causes severe irritation the nose, skin and eyes.
How Calcium Oxide is Prepared

Chemical Reaction: $\mathrm{CaCO}_{3}(\mathrm{~s}) \rightarrow \mathrm{CaO}(\mathrm{s})+\mathrm{CO}_{2}$ (g)
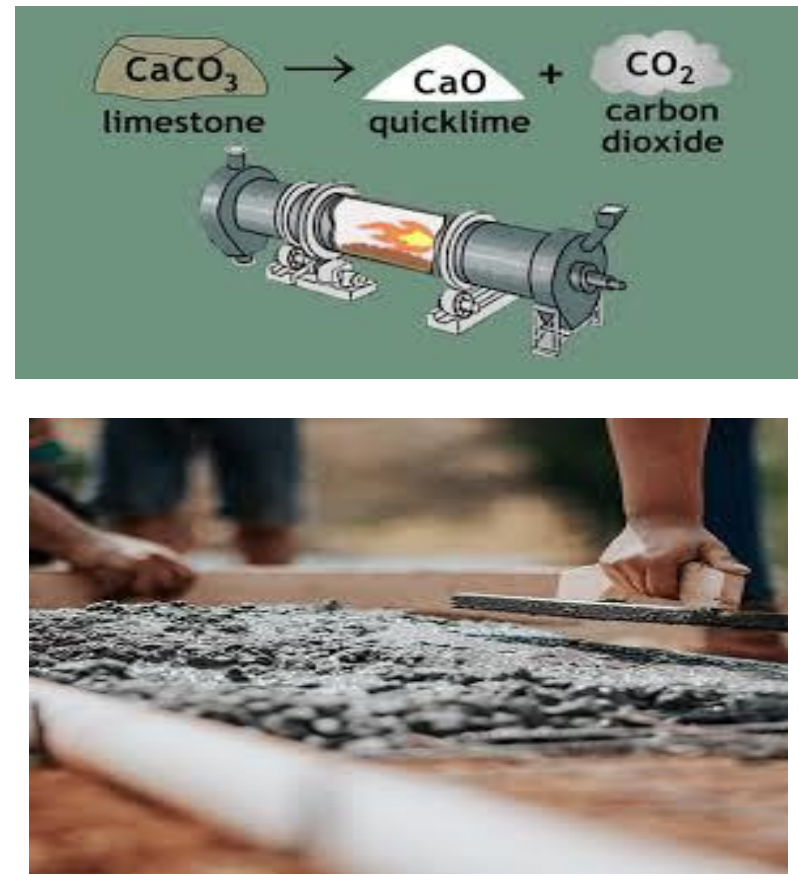

Figure 9: How Calcium Oxide is prepared (youtube.com)

Calcium oxide is produced by decomposition through heat in a rotary lime kiln at high temperatures ranging between $1070^{\circ} \mathrm{C}$ and $1270^{\circ} \mathrm{C}$ (below melting point) on substances that contain calcium carbonate $\left(\mathrm{CaCO}_{3}\right)$ which forms burnt lime and carbon dioxide. This process is called calcination.

\section{LITERATURE REVIEW}

The term high pressure / high temperature (HPHT) was first mentioned around 1990 (Drake and Callaway, 2014; Wilson, 2006). The calcium oxide has a white color, a shape that is spherical, narrow particles size distribution with high porosity (Tangboriboon, Kunanuruksapong and Sirivat, 2012). Cement pastes which contains ceramic waste produced hydrated products of low $\mathrm{Ca} / \mathrm{Si}$ ratios when combined with silica flour that sustains the compressive strength levels satisfactorily (Souza et al, 2012). A more reliable of fluid loss additive is seen in fresh water cement slurry than in salty one (Qiang, Pinhua and Wenfa , 2014). Volumetric shrinkage of cement slurry during oilwell cementing has been a problem that is of priority (Beirute and Tragesser, 1973; Mehta, 1978; Chenevert and Shrestha, 1987). The estimated apparent activation energy of the different cements at $2 \mathrm{MPa}$ varies from $38.7 \mathrm{~kJ} / \mathrm{mol}$ to $41.4 \mathrm{~kJ} / \mathrm{mol}$ for the temperature range of $25^{\circ} \mathrm{C}$ to $40^{\circ} \mathrm{C}$, which reduces a little with increasing curing temperature and pressure (Xueyu et al, 2013). CaO plays an essential role in biologic response during the mineralization process (Estrela et al, 2012). The application of CaO-based expansive agent permits obtaining low porous cement matrix (Valeria, Jacopo and Alessandro, 2015).

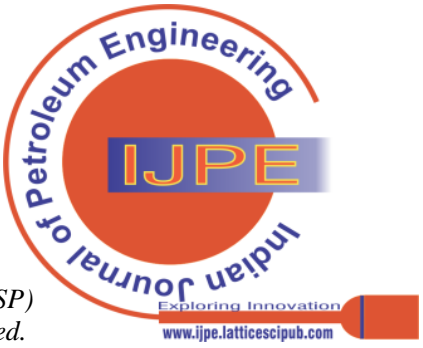




\section{MATERIAL AND METHODS}

This paper discusses HPHT and the Calcium Oxide as the right additive for cementation in production HPHT wells. The method adopted is review of calcium oxide as a better additive candidate for cement slurry production utilized for HPHT wells.

\section{DATA AND METHODOLOGY}

Considering Appah D. and Reichetseder P. (2001), using
- permeabilities of 3 different $\mathrm{CaO}$-cement paste which depends on temperature.

- $\quad$ consistency curves of 4 different $\mathrm{CaO}$-expanding cements at a temperature of $70{ }^{\circ} \mathrm{C}$ and pressure of 43.5 MPa.

- $\quad$ compressive strength ( $\mathrm{MPa}$ ) curves for 3 different $\mathrm{CaO}$-cement paste. the:

Table 1: Permeabilities of 3 different $\mathrm{CaO}$-cement paste which depends on temperature.

\begin{tabular}{|c|c|c|c|c|}
\hline & & meability $\left[\mathrm{mm}^{2}(\mathrm{micr}\right.$ & y)] & Temperature $^{\circ} \mathrm{C}$ \\
\hline & $\begin{array}{l}\text { CaO-expanding } \\
\text { cements } 1\end{array}$ & $\begin{array}{l}\text { CaO-expanding } \\
\text { cements } 2\end{array}$ & $\begin{array}{l}\text { CaO-expanding } \\
\text { cements } 3\end{array}$ & \\
\hline & 0.08 & 0.03 & 0.05 & 50 \\
\hline & 0.2 & 0.57 & 0.17 & 60 \\
\hline & 0.23 & 0.65 & 0.18 & 65 \\
\hline & 0.2 & 0.6 & 0.19 & 70 \\
\hline & 0.17 & 0.36 & 0.19 & 78 \\
\hline & 0.1 & 0.29 & 0.2 & 80 \\
\hline & 0.18 & 0.2 & 0.23 & 87 \\
\hline & 0.2 & 0.18 & 0.3 & 90 \\
\hline & 0.78 & 0.23 & 0.4 & 95 \\
\hline & 0.78 & 1 & 1.14 & 110 \\
\hline Regression $\left(\mathbf{R}^{2}\right)$ & 0.0903 & 0.527 & 0.6387 & \\
\hline Equation & $y=0.0049 x+0.0282$ & $y=0.0106 x-0.5406$ & $\mathrm{y}=0.0137 \mathrm{x}-0.7716$ & \\
\hline
\end{tabular}

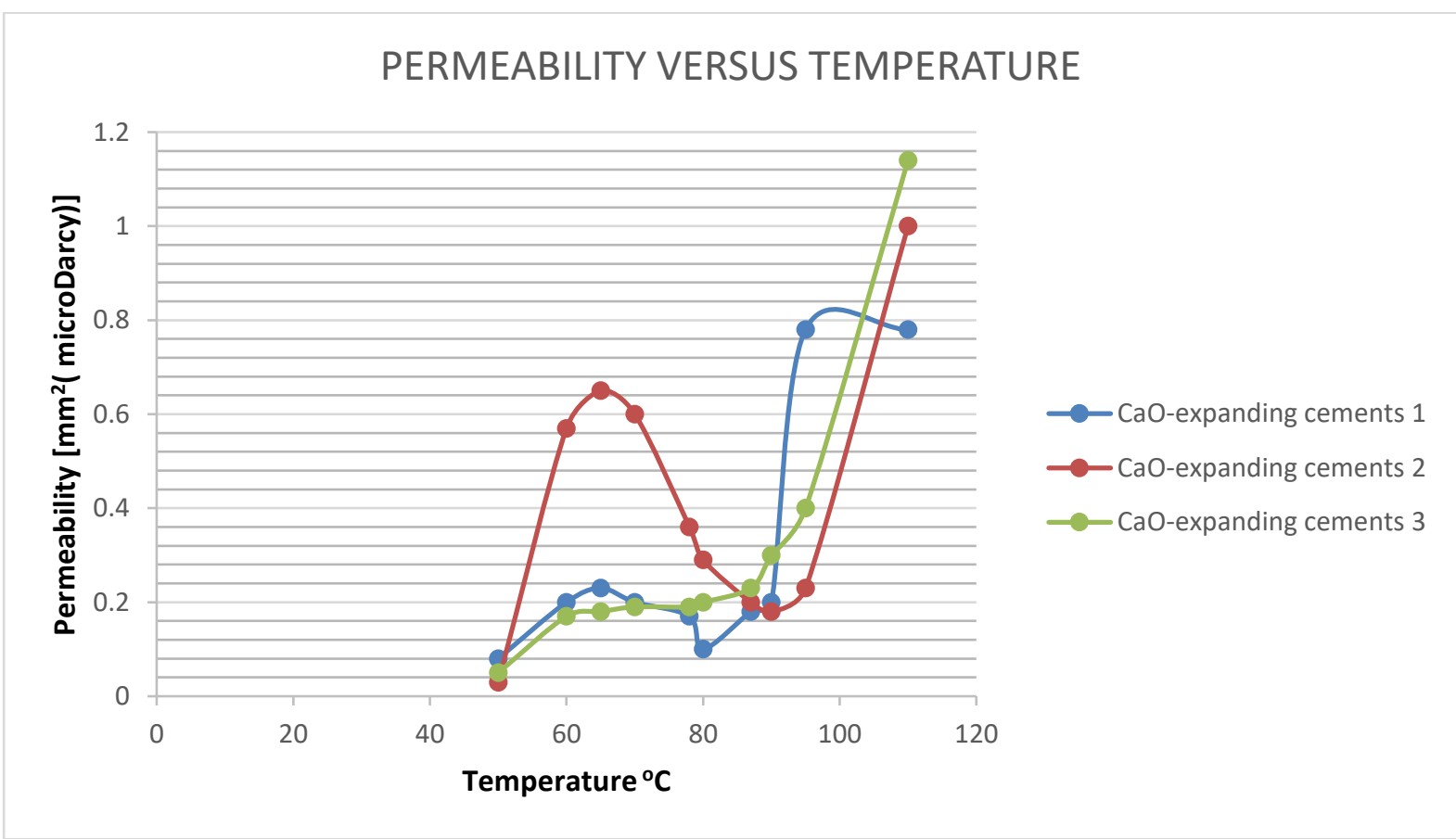

Figure 10: Permeability versus Temperature

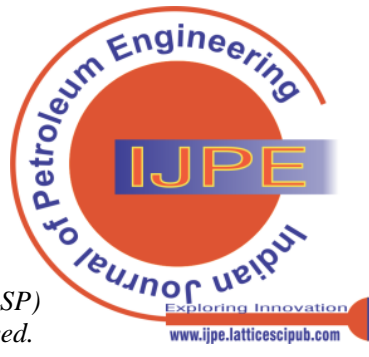


Table 2: Consistency curves of 4 different $\mathrm{CaO}$-expanding cements at a temperature of $70^{\circ} \mathrm{C}$ and pressure of 43.5 MPa.

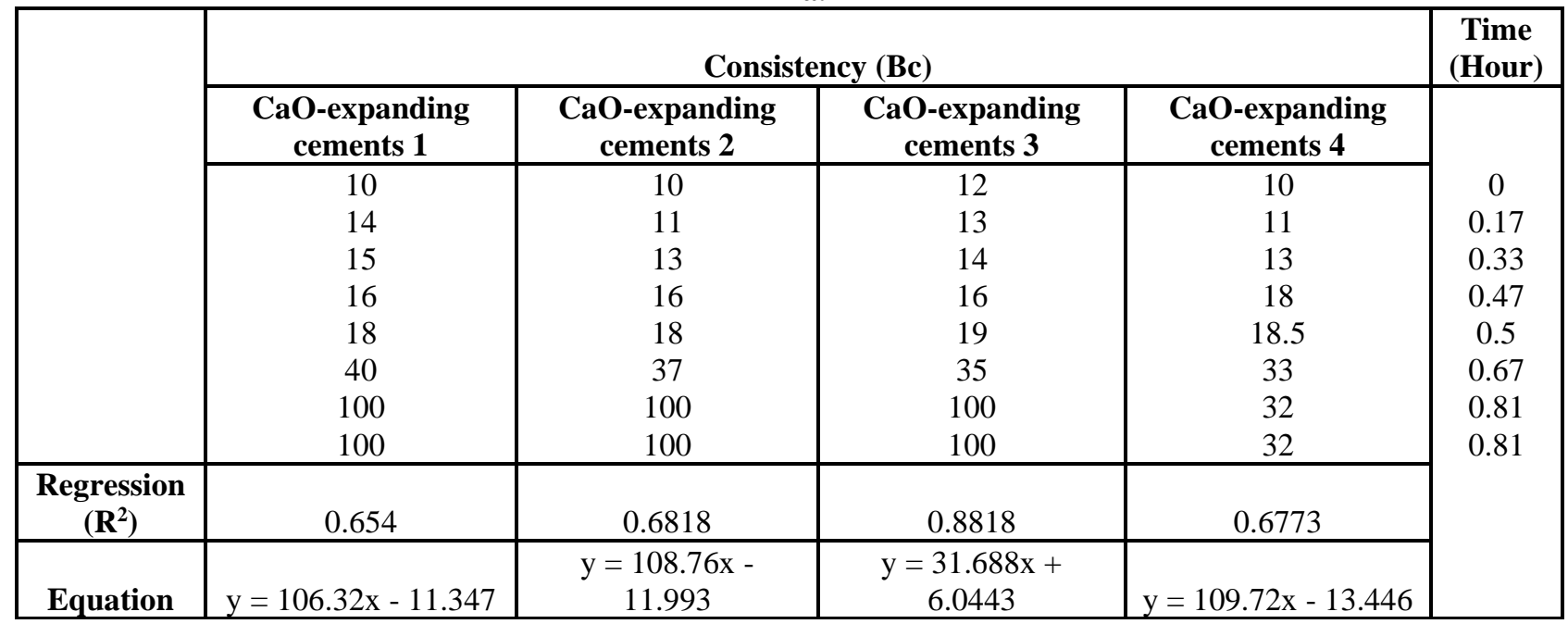

\section{CONSISTENCY VERSUS TIME}

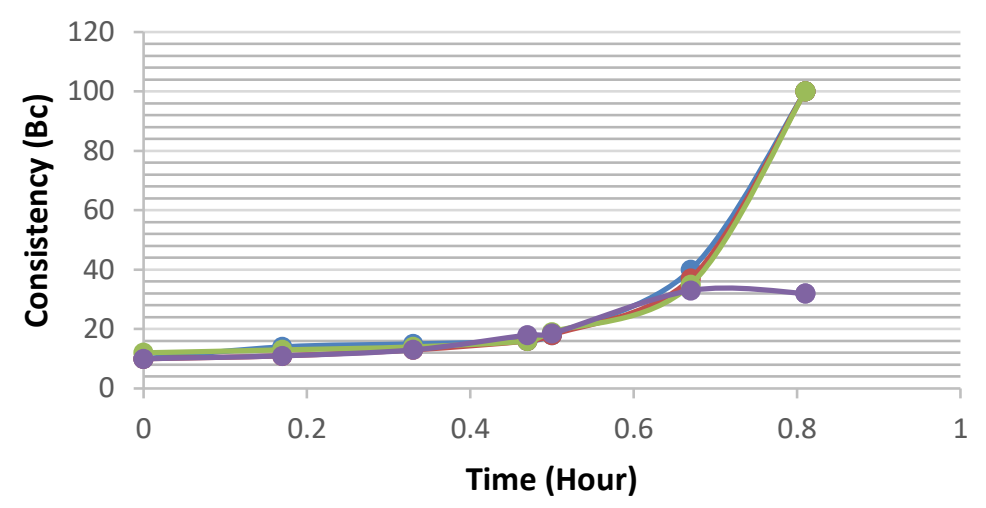

-CaO-expanding cements 1

$\longrightarrow$ CaO-expanding cements 2

-CaO-expanding cements 3

-CaO-expanding cements 4

Figure 11: Consistency versus Time

Table 3: Compressive strength (MPa) curves for 3 different CaO-cement paste.

\begin{tabular}{|c|c|c|c|c|}
\hline & \multicolumn{3}{|c|}{ Compressive Strength (Mpa) } & \multirow[t]{2}{*}{ Temperature $^{\circ} \mathrm{C}$} \\
\hline & $\begin{array}{c}\text { CaO-expanding } \\
\text { cements } 1\end{array}$ & $\begin{array}{c}\text { CaO-expanding } \\
\text { cements } 2\end{array}$ & $\begin{array}{c}\text { CaO-expanding } \\
\text { cements } 3\end{array}$ & \\
\hline & 40.8 & 45.1 & 42 & 50 \\
\hline & 42 & 43.8 & 41.9 & 60 \\
\hline & 42.8 & 43.8 & 41 & 65 \\
\hline & 43.3 & 44 & 40.9 & 67 \\
\hline & 43.9 & 45.2 & 40.7 & 70 \\
\hline & 45 & 47.4 & 40.3 & 75 \\
\hline & 45.8 & 48.3 & 40.5 & 80 \\
\hline & 44.5 & 45.5 & 43.1 & 90 \\
\hline & 43.8 & 43.8 & 44.1 & 95 \\
\hline & 43.7 & 43 & 44.3 & 98 \\
\hline & 43.5 & 42.8 & 44.1 & 100 \\
\hline & 43.4 & 41.4 & 43 & 110 \\
\hline Regression $\left(\mathbf{R}^{2}\right)$ & 0.4611 & 0.1713 & 0.2291 & \\
\hline Equation & $\mathrm{y}=0.0554 \mathrm{x}+37.727$ & $y=-0.0433 x+47.969$ & $y=0.0339 x+40.83$ & \\
\hline
\end{tabular}




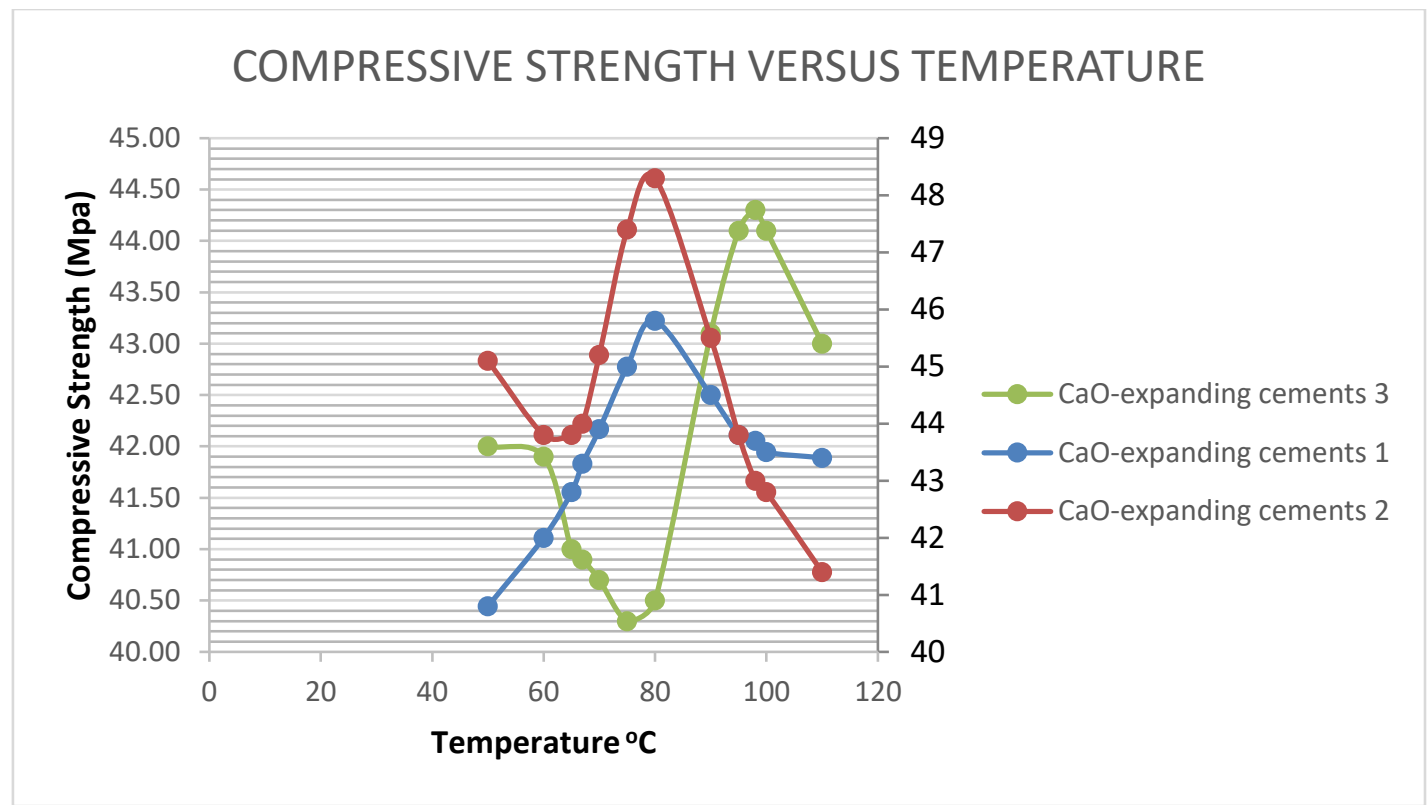

Figure 12: Compressive Strength versus Temperature

Table 4: Summary of Results

\begin{tabular}{|c|c|c|c|c|c|c|c|c|c|c|}
\hline \multirow[t]{2}{*}{ S/No. } & \multicolumn{3}{|c|}{$\begin{array}{c}\text { Permeability Versus } \\
\text { Temperature }\end{array}$} & \multicolumn{4}{|c|}{ Consistency Versus Time } & \multicolumn{3}{|c|}{$\begin{array}{c}\text { Compressive Strength } \\
\text { Versus Temperature }\end{array}$} \\
\hline & $\begin{array}{l}\text { CaO- } \\
\text { exp. } \\
\text { Cem. } 1\end{array}$ & $\begin{array}{l}\text { CaO- } \\
\text { exp. } \\
\text { Cem. } 2\end{array}$ & $\begin{array}{l}\text { CaO- } \\
\text { exp. } \\
\text { Cem. } 3\end{array}$ & $\begin{array}{l}\text { CaO- } \\
\text { exp. } \\
\text { Cem. } 1\end{array}$ & $\begin{array}{l}\text { CaO- } \\
\text { exp. } \\
\text { Cem. } 2\end{array}$ & $\begin{array}{c}\text { CaO- } \\
\text { exp. } \\
\text { Cem. } 3\end{array}$ & $\begin{array}{l}\text { CaO- } \\
\text { exp. } \\
\text { Cem. } 4\end{array}$ & $\begin{array}{l}\text { CaO- } \\
\text { exp. } \\
\text { Cem. } 1\end{array}$ & $\begin{array}{l}\text { CaO- } \\
\text { exp. } \\
\text { Cem. } 2\end{array}$ & $\begin{array}{c}\text { CaO- } \\
\text { exp. } \\
\text { Cem. } 3\end{array}$ \\
\hline $\begin{array}{c}\text { Regression } \\
\left(\mathbf{R}^{2}\right)\end{array}$ & 0.0903 & 0.527 & 0.6387 & 0.654 & 0.6818 & 0.8818 & 0.6773 & 0.4611 & 0.1713 & 0.2291 \\
\hline Equation & $\begin{array}{c}\mathrm{y}= \\
0.0049 \mathrm{x} \\
+ \\
0.0282\end{array}$ & $\begin{array}{c}y= \\
0.0106 \mathrm{x} \\
- \\
0.5406\end{array}$ & $\begin{array}{c}\mathrm{y}= \\
0.0137 \mathrm{x} \\
- \\
0.7716\end{array}$ & $\begin{array}{c}y= \\
106.32 \mathrm{x} \\
- \\
11.347\end{array}$ & $\begin{array}{c}\mathrm{y}= \\
108.76 \mathrm{x} \\
- \\
11.993\end{array}$ & $\begin{array}{c}y= \\
31.688 \mathrm{x} \\
+ \\
6.0443\end{array}$ & $\begin{array}{c}y= \\
109.72 x \\
- \\
13.446\end{array}$ & $\begin{array}{c}\mathrm{y}= \\
0.0554 \mathrm{x} \\
+ \\
37.727\end{array}$ & $\begin{array}{c}\mathrm{y}=- \\
0.0433 \mathrm{x} \\
+ \\
47.969\end{array}$ & $\begin{array}{c}y= \\
0.0339 x \\
+40.83\end{array}$ \\
\hline
\end{tabular}

\section{RESULTS AND DISCUSSION}

In figure 10, the permeability of three cement pastes was considered against different temperature. The three samples selected had similar trends beginning from $50^{\circ} \mathrm{C}$. Cement 1 rose to its first permeability peak of 0.22 microDarcy at 70 ${ }^{\circ} \mathrm{C}$ which fell to 0.05 microDarcy at $80^{\circ} \mathrm{C}$ but later peaked straight to 0.8 microDarcy at $90^{\circ} \mathrm{C}$ that eventually plunged to 0.9 microDarcy at $110{ }^{\circ} \mathrm{C}$. Cement 2 rose to its first permeability peak of 0.65 microDarcy at $65{ }^{\circ} \mathrm{C}$ which fell to 0.08 microDarcy at $90^{\circ} \mathrm{C}$ but later sky-rocketed straight to 1.0 microDarcy at $110^{\circ} \mathrm{C}$. Cement 3 rose to its first permeability peak of 0.60 microDarcy at $70{ }^{\circ} \mathrm{C}$ which fell to 0.28 microDarcy at $90^{\circ} \mathrm{C}$ but later sky-rocketed straight to 1.7 microDarcy at $110^{\circ} \mathrm{C}$.

In figure 11, the consistency of four cement pastes were considered against time. The four samples chosen had similar trends beginning from 0Bc.Cement 1 rose proportionately up to $40 \mathrm{Bc}$ for 0.67 hours which further curved away till $100 \mathrm{Bc}$ for another 0.13 hours. Cement 2 went up as well proportionately up to $37 \mathrm{Bc}$ for the same length of time till 100Bc. Cement 3 followed suit up to 35Bc for same length of time till $100 \mathrm{Bc}$. Cement 4 rose up to $33 \mathrm{Bc}$ for same length of time, but decreased to 32Bc for another 0.13hours.
In figure 12, the compressive strength of three cement pastes were considered against temperature. The three samples used had similar trends beginning from $50^{\circ} \mathrm{C}$. Cement 1 initially possessed the compressive strength of $40.5 \mathrm{MPa}$ at this temperature, but peaked to $43.3 \mathrm{MPa}$ at $75^{\circ} \mathrm{C}$ which later dropped continuously till $41.53 \mathrm{MPa}$ at $110^{\circ} \mathrm{C}$. Cement 2 initially had the compressive strength of $45 \mathrm{MPa}$ at this temperature which peaked at $48.3 \mathrm{MPa}$ at $80^{\circ} \mathrm{C}$, but dropped continuously till $42 \mathrm{MPa}$ at $110^{\circ} \mathrm{C}$. Cement 3 initially had the compressive strength of $42 \mathrm{MPa}$ at this temperature, but peaked to $40.2 \mathrm{MPa}$ at $75^{\circ} \mathrm{C}$ which later increased continuously till $44.3 \mathrm{MPa}$ at $100^{\circ} \mathrm{C}$ and fell to $43 \mathrm{MPa}$ at $110^{\circ} \mathrm{C}$.

Considering correlation regression in table 4 , cement 1 performed poorly in its cement permeability; cement 2 was on the average and cement 3 went above average posing as the best. Cement 1, 2 and 3 went above average in their cement consistency, but cement 3 is the best. Cement 1,2 and 3 went below average in their cement compressive strength, but cement 1 is best.

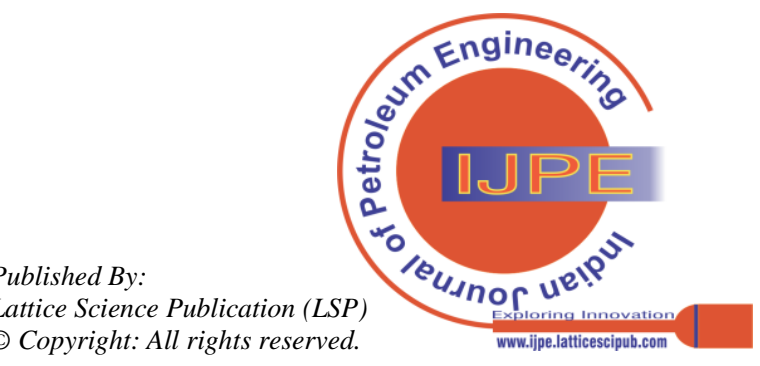




\section{CONCLUSION AND RECOMMENDATION}

For Calcium Oxide to perform its functions as good cement expanders, the permeability should be increased to about 63\%; its consistency to $88 \%$ and its compressive strength to above $46 \%$. This will be able to meet up the challenge of high pressure and high temperature downhole cement operations.

\section{REFERENCES}

1. Appah D. and Reichetseder P. (2001): Selection and use of CaOExpanding Cements; Energy Exploration \& Exploitation, Volume 19 - Number 6 · 2001 pp 581-591. [CrossRef]

2. Beirute R.M. and Tragesser M. (1973): Expansive and Shrinkage Characteristics of Cements under Actual Well Conditions, JPT, Aug., pp. 905-909.Chenevert M.E. and Shresthra B. (1987): Shrinkage Properties of Cement, SPE annual Technical Conf. \& Exhibition, Dallas-Texas, U.S.A., paper 16654, Sept. 27-30, pp. 4957. [CrossRef]

3. DGMK (1994): Development and Testing of Swelling Cements for Gas Wells, Research Report 444-2, Hamburg, Germany, pp128. [CrossRef]

4. DGMK (1997): Development and Testing of Swelling Cements into Usage Maturity for Cementation of Natural Gas Underground Storage Wells and Natural Gas Production Wells, Research Report 444-3, Hamburg, Germany, pp.104

5. DGMK (2000): Development CaO-Swelling Cements for Cementing of Natural Gas Underground Storage Wells in Field Trial (Temperature Range $£ 60^{\circ} \mathrm{C}$ ) and Composition of $\mathrm{CaO}$ - and $\mathrm{MgO}$ Swelling Cements for a Temperature Range between $60^{\circ} \mathrm{C}-105^{\circ} \mathrm{C}$ ), Research Report 444-4, Hamburg, Germany, pp.78.

6. Drake K. and Callaway R. (2014): New Polymeric Materials Development for Extreme Environments, OTC-25304, Offshore Technology Conference, Houston Texas, USA, 5-8, 2014 [CrossRef]

7. Estrela C, Sousa-Neto MD, Guedes OA, Alencar AH, Duarte MA Pécora JD. Characterization of calcium oxide in root perforation sealer materials. Braz Dent J. 2012;23:539-46. [CrossRef]

8. Mehta P.K. (1978): History and Status of Performance Test for Evaluation of Soundness of Cements, Cement Standards-Evaluation and Trends, ASTM STP 663, 35. [CrossRef]

9. Souza et al. (2012): Cement Slurries of Oil Wells Under High Temperature And Pressure - The Effects of the Use Of Ceramic Waste And Silica Flour; Brazillian Journal Of Petroleum And Gas, Vol. 6, No. 3. [CrossRef]

10. Tangboriboon N., Kunanuruksapong R. and Sirivat A. (2012):Preparation and properties of calcium oxide from eggshells via calcination; Materials Science-Poland, volume 30, pages313322. [CrossRef]

11. Qiang X., Pinhua R. and Wenfa X. (2014): Preparation of a novel for polymer as fluid loss additive for high temperature oil well cementing, Springer; Russian Journal of Applied Chemistry, volume 87, pages 1377-1381. [CrossRef]

12. Xueyu P., Walmy C., Benjamin J. and Iverson J. (2013): Hydration kinetics modeling of the effect of curing temperature and pressure on the heat evolution of oil well cement, Volume 54, Pages 69-76. [CrossRef]

13. Valeria C., Jacopo D. and Alessandro N.(2015): The influence of calcium oxide addition on properties of fiber reinforced cementbased composites.

14. Wilson, S. M. (2006): Feeling the heat, Can't stand the pressure? First Break, Volume 24, No. 5. [CrossRef]

15. Zhaoguang Y., Jerome J.S., Catalin T. and Paolo G.(2012): HPHT Gas Well Cementing Complications and its Effect on Casing Collapse Resistance, Researchgate. [CrossRef]

16. Bomá W., Babs M.O. and Islam S.(2016): HT Well Integrity and Cement Failure ,SPE Nigeria Annual International Conference and Exhibition, Researchgate.

17. Shado Y. and Ogbonna J. 2011():Challenges and Remedy for Cementing of HPHT Wells in Nigerian Operation

18. Michael C.(2017): Integrating MPD into HPHT Well Planning , Abu Dhabi International Petroleum Exhibition \& Conference, Researchgate.

19. Arpit S. et al. (2019): Challenges in HPHT Well: A Case Study, SPE Oil and Gas India Conference and Exhibition, Researchgate.

20. Woha G., Ogbonna J. and Boniface O. (2011): Advances in Mud Design and Challenges in HPHT Wells, Researchgate

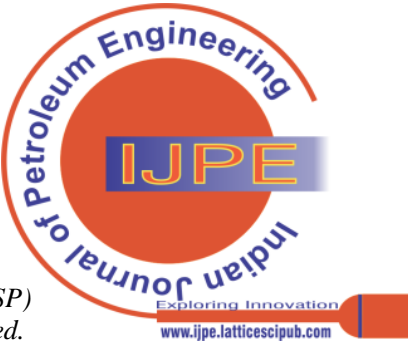

